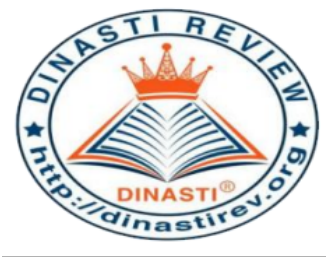

+62 878-9658-6407

087896586407

https://dinastirev.org/JIMT

editor@dinastirev.org

\title{
IMPLEMENTASI ETIKA BISNIS DAN GOOD CORPORATE GOVERNANCE PADA PERKEBUNAN KELAPA SAWIT PT. BUMITAMA GUNAJAYA AGRO
}

\section{Partini Kusmiarti ${ }^{1}$}

1) Universitas Mercu Buana, Jakarta, Indonesia

\begin{tabular}{|c|c|}
\hline $\begin{array}{l}\quad \text { ARTICLE INFORMATION } \\
\text { Received : 2 Januari } 2020 \\
\text { Revised : 6 Januari 2020 } \\
\text { Issued : 10 Januari } 2020 \\
\text { Corresponding author: } \\
\text { Partini Kusmiarti } \\
\text { E-mail: } \\
\text { pkusmiarti@gmail.com }\end{array}$ & $\begin{array}{l}\text { Abstrak: Sebagai negara yang memiliki jumlah } \\
\text { penduduk yang besar, Indonesia menjadi pangsa bisnis } \\
\text { yang menjanjikan, karena itulah semakin baik untuk } \\
\text { mengembangkan bisnis di segala bidang. terlebih } \\
\text { ditunjang berlimpahnya Sumber Daya Alam. Hal ini } \\
\text { membuat berbagai perusahaan tumbuh pesat di } \\
\text { Indonesia. Tidak hanya menyumbangkan dampak } \\
\text { positif, tetapi juga ada dampak negatif berupa } \\
\text { eksternalitas yang semakin meningkat. Pelaku bisnis } \\
\text { perlu diingatkan untuk memberikan fokus pada } \\
\text { antisipasi dampak negatif, tidak hanya berorientasi pada } \\
\text { keuntungan. Perusahaan PT Bumitama (BGA), sebagai } \\
\text { perusahaan publik, dalam pengelolaannya telah } \\
\text { menjalankan bisnis secara beretika. Tidak hanya } \\
\text { berorientasi pada profit, tetapi menggunakan cara-cara } \\
\text { yang beretika dan taat hukum serta peraturan } \\
\text { perundang-undangan yang berlaku untuk mendapatkan } \\
\text { profit. Selain itu BGA juga menjalankan Tata Kelola } \\
\text { Perusahaan yang Baik (Good Corporate Governance } \\
\text { disingkat GCG). Prinsip-prinsip GCG seperti: } \\
\text { Transparansi, Akuntabilitas, Pertanggungjawaban, } \\
\text { Kemandirian, Kewajaran dan Kesetaraan. Prinsip- } \\
\text { prinsip tersebut merupakan kewajiban bagi setiap } \\
\text { karyawan dalam menjalankan tugas dan tanggung } \\
\text { jawabnya sehari-hari. } \\
\text { Kata Kunci: Jumlah Penduduk Besar; Peluang Bisnis, } \\
\text { Etika Bisnis, Tatakelola Perusahaan yang Baik }\end{array}$ \\
\hline
\end{tabular}

\section{PENDAHULUAN}

Negara Indonesia memiliki jumlah penduduk pada Tahun 2018, menurut data Perserikatan Bangsa Bangsa (PBB) mencapai 266,79 juta jiwa, berada di urutan ke empat sebagai Negara dengan jumlah populasi terbesar di dunia, dibawah Tiongkok, India dan Amrerika Serikat. Sebagai negara yang memiliki jumlah penduduk yang besar, Indonesia menjadi pangsa bisnis yang besar dan menjanjikan, terlebih ditunjang berlimpahnya Sumber Daya Alam (SDA) yang semakin baik untuk mengembangkan bisnis di segala bidang. Hal ini membuat berbagai perusahaan tumbuh pesat di Indonesia. Selain menyumbangkan dampak 
positif, pertumbuhan perusahaan perusahaan tersebut juga membawa dampak negatif, berupa eksternalitas yang semakin meningkat. Namun demikian, sebagai sebuah entitas bisnis, pada kenyataannya ada pelaku bisnis yang belum memberikan fokus pada dampak negatif tersebut. Pada Tahun 1999 negara-negara di Asia Timur yang terkena krisis mulai mengalami pemulihan, termasuk Indonesia yang mengalami krisis multidimensi sejak Juli 1997, menggugah kesadaran banyak pihak tentang kekeliruan anggapan lama bahwa bisnis bisa bertahan dan berhasil dalam jangka panjang hanya dengan mengandalkan permainan curang. Muncul kesadaran baru betapa penting dan relevansinya etika bisnis dan tata kelola perusahaan yang baik (Good Corporate Governance). Bahwa untuk bisa berhasil, mendatangkan untung, perusahaan wajib menjalankan bisnis secara etis dan didukung dengan tata kelola perusahaan yang baik. Salain itu harus dipahami bahwa kompetisi global bukan kompetisi antar negara, melainkan antar korporat di negara- negara tersebut. Jadi menang atau kalah, menang atau terpuruk, pulih atau tetap terpuruknya perekonomian satu negara bergantung pada korporat masing-masing (Moeljono, 2005).

Pada akhirnya dengan adanya krisis multidimensi tersebut istilah Good Corporate Governance (GCG) kian populer, istilah tersebut ditempatkan di posisi terhormat. Pertama, GCG merupakan salah satu kunci sukses perusahaan untuk tumbuh dan menguntungkan dalam jangka panjang, sekaligus memenangkan persaingan bisnis global. Kedua, krisis ekonomi di kawasan Asia dan Amerika Latin yang diyakini muncul karena kegagalan penerapan GCG (Daniri, 2005). Perhatian terhadap corporate governance terutama juga dipicu oleh skandal spektakuler seperti, Enron, Worldcom, Tyco, London \& Commonwealth, Poly Peck, Maxwell, dan lain-lain. Keruntuhan perusahaan-perusahaan publik tersebut dikarenakan oleh kegagalan strategi maupun praktek curang dari manajemen puncak yang berlangsung tanpa terdeteksi dalam waktu yang cukup lama karena lemahnya pengawasan yang independen oleh corporate boards.

Pemahaman tersebut membuka wawasan bahwa korporat kita belum dikelola secara benar. Dalam bahasa khusus, korporat kita belum menjalankan governansi (Moeljono, 2005). Survey dari Booz-Allen di Asia Timur pada tahun 1998 menunjukkan bahwa Indonesia memiliki indeks corporate governance paling rendah dengan skor 2,88 jauh di bawah Singapura $(8,93)$, Malaysia $(7,72)$ dan Thailand $(4,89)$. Rendahnya kualitas GCG korporasi-korporasi di Indonesia ditengarai menjadi kejatuhan perusahaan- perusahaan tersebut.

Etika Bisnis dan Good Corporate Governance menjadi perhatian dunia usaha akhir-akhir ini. Tingkat urgensinya ditentukan karena dalam jangka panjang apabila perusahaan tidak concern dengan etika bisnis, maka kelangsungan hidupnya akan terganggu. Studi terhadap banyak perusahaan di AS menunjang kenyataan tersebut. Yang berkewajiban untuk menjadi etika dalam komunitas bisnis itu sendiri. Tetapi bila tidak dapat dipenuhi, pemerintah berkewajiban untuk mengaturnya (Bertens, 1993). Di Indonesia, etika bisnis masih merupakan sesuatu yang baru. Meskipun para pelaku bisnis atau manager di Indonesia memiliki etika, namun etika yang dilakukannya masih merupakan bagian dari etika sosial atau etika individual.

\section{KAJIAN PUSTAKA}

\section{Etika Bisnis (Business Ethic)}

Di Indonesia, perilaku etika bisnis manajer dan tanggung jawab perusahaan pada lingkungan sosial merupakan suatu hal yang menarik untuk dikaji, terutama etika bisnis dan tanggung jawab pada lingkungan sosial. Muslich (1998) menyatakan bahawa etika bisnis diartikan sebagai pengetahuan tentang cara ideal pengaturan dan pengelolaan bisnis yang memperhatikan norma dan normalitas yang berlaku secara universal dan secara 
ekonomi/sosial, dan pengetrapan norma dan normalitas ini menjunjung maksud dan tujuan kegiatan bisnis.

Dikatakan oleh Silalahi (2003) bahwa bisnis terdiri dari hal-hal yang berkaitan dengan industri, trading, keuangan dan jasa. Aktivitas bisnis terjadi kalau ada interaksi antara konsumen dan produsen yang mana produsen menyediakan kebutuhan yang dibutuhkan oleh konsumen dan meminta imbalan uang demi kebutuhan tertentu. Bila tidak ada konsumen, bisnispun tidak mungkin ada.

Tujuan etika bisnis adalah menggugah kesadaran moral para pelaku bisnis untuk menjalankan good business dan tidak melakukan monkey business atau dirty business. Etika bisnis mengajak para pelaku bisnis mewujudkan citra dan manajemen bisnis yang baik (etis) agar bisnis itu pantas dimasuki oleh semua orang yang mempercayai adanya dimensi etis dalam dunia bisnis. Hal ini sekaligus menghalau citra buruk dunia bisnis sebagai kegiatan yang kotor, licik, dan tipu muslihat. Kegiatan bisnis mempunyai implikasi etis, dan oleh karenanya membawa serta tanggungjawab etis bagi pelakunya.

\section{Etika Bisnis Dalam Kehidupan Bisnis}

Mempraktikkan bisnis dengan etiket berarti mempraktikkan tata cara bisnis yang sopan dan santun sehingga kehidupan bisnis menyenangkan karena saling menghormati. Etiket berbisnis diterapkan pada sikap kehidupan berkantor, sikap menghadapi rekan-rekan bisnis, dan sikap dimana kita tergabung dalam organisasi. Itu berupa 3 S, Senyum Salam Sapa sebagai apresiasi yang tulus dan terima kasih, tidak menyalahgunakan kedudukan, kekayaan, tidak lekas tersinggung, kontrol diri, toleran, dan tidak memotong pembicaraan orang lain.

Dengan kata lain, etika bisnis itu memelihara suasana yang menyenangkan, menimbulkan rasa saling percaya, saling menghargai, meningkatkan efisiensi kerja, dan meningkatkan citra pribadi dan juga citra perusahaan. Berbisnis dengan etika bisnis adalah menerapkan aturanaturan umum mengenai etika pada perilaku bisnis. Etika bisnis menyangkut moral, kontak sosial, hak-hak dan kewajiban, prinsip- prinsip dan aturan-aturan.

\section{Sasaran dan ruang lingkup Etika Bisnis:}

Ada tiga sasaran dan ruang lingkup pokok yang harus diperhatikan supaya tujuan dari etika bisnis bisa tercapai, yaitu:

1. Etika bisnis sebagai etika profesi, membahas berbagai prinsip, kondisi, dan masalah yang terkait dengan praktek bisnis yang baik dan etis. Dengan kata lain, etika bisnis pertama-tama bertujuan untuk menghimbau para pelaku bisnis untuk menjalankan bisnis secara baik dan etis.

2. Menyadarkan masyarakat, khususnya konsumen, pekerja, atau karyawan dan masyarakat luas pemilik aset umum semacam lingkungan hidup, akan hak dan kepentingan mereka yang tidak boleh dilanggar oleh praktek bisnis siapa pun juga. Pada tingkat ini, etika bisnis berfungsi untuk menggugah masyarakat untuk bertindak menuntut para pelaku bisnis untuk berbisnis secara baik demi terjaminnya hak dan kepentingan masyarakat tersebut. Etik bisnis mengajak masyarakat luas, entah sebagai karyawan, konsumen, atau pemakai aset umum lainnya yang berkaitan dengan kegiatan bisnis, untuk sadar dan berjuang menuntut haknya atau paling kurang agar hak dan kepentingannya tidak dirugikan oleh kegiatan bisnis.

3. Etika bisnis juga berbicara mengenai sistem ekonomi yang sangat menentukan etis tidaknya suatu praktek bisnis. Dalam hal ini, etika bisnis lebih bersifat makro, yang 
karena itu barang kali lebih tepat disebut etika ekonomi. Dalam lingkup makro semacam ini, etika bisnis berbicara mengenai monopoli, oligopoli, kolusi, dan praktek-praktek semacamnya yang akan sangatmempengaruhi tidak saja sehat tidaknya suatu ekonomi melainkan juga baik tidaknya praktek bisnis dalam sebuah Negara.

\section{Good Corporate Governance (GCG)}

\section{Pengertian Konsep dan dasar}

Corporate governance adalah suatu proses dan struktur yang digunakan oleh organ Perusahaan untuk meningkatkan keberhasilan usaha dan akuntabilitas perusahaan guna mewujudkan nilai pemegang saham dalam jangka panjang dengan tetap memperhatikan kepentingan stakeholders lainnya, berlandaskan peraturan perundangan dan nilai-nilai etika. Organ perusahaan adalah RUPS, Komisaris, Direksi, Pemilik Modal. Sedangkan stakeholders adalah pihak-pihak yang memiliki kepentingan dengan BUMN, baik langsung maupun tidak langsung yaitu Pemegang Saham/Pemilik Modal, Komisaris/Dewan Pengawas, Direksi dan Karyawan serta Pemerintah, Kreditur, dan pihak berkepentingan lainnya.

Dua teori utama yang terkait dengan corporate governance adalah stewardship theory dan agency theory (Chinn, 2000; Shaw, 2003). Stewardship theory dibangun di atas asumsi filosofis mengenai sifat manusia yakni bahwa manusia pada hakekatnya dapat dipercaya, mampu bertindak dengan penuh tanggung jawab, memiliki integritas dan kejujuran terhadap pihak lain. Inilah yang tersirat dalam hubungan fidusia yang dikehendaki para pemegang saham. Dengan kata lain, stewardship theory memandang manajemen sebagai dapat dipercaya untuk bertindak dengan sebaik- baiknya bagi kepentingan publik maupun stakeholder.

Agency theory yang dikembangkan oleh Michael Johnson, memandang bahwa manajemen perusahaan sebagai "agents" bagi para pemegang saham, akan bertindak dengan penuh kesadaran bagi kepentingannya sendiri, bukansebagai pihak yang arif dan bijaksana serta adil terhadap pemegang saham. Dalam perkembangan selanjutnya, agency theory mendapat respon lebih luas karena dipandang lebih mencerminkan kenyataan yang ada. Berbagai pemikiran mengenai corporate governance berkembang dengan bertumpu pada agency theory di mana pengelolaan dilakukan dengan penuh kepatuhan kepada berbagai peraturan dan ketentuan yang berlaku.

Good corporate governance (GCG) secara definitif merupakan sistem yang mengatur dan mengendalikan perusahaan yang menciptakan nilai tambah (value added) untuk semua stakeholder (Monks,2003). Ada dua hal yang ditekankan dalam konsepini, pertama, pentingnya hak pemegang saham untuk memperoleh informasi dengan benar dan tepat pada waktunya dan, kedua, kewajiban perusahaan untuk melakukan pengungkapan (disclosure) secara akurat, tepat waktu, transparan terhadap semua informasi kinerja perusahaan, kepemilikan, dan stakeholder.

Menurut Forum for Corporate Governance in Indonesia (FCGI) mendefinisikan Corporate Governance sebagai seperangkat peraturan yang mengatur hubungan antara pemegang, pengurus (pengelola) perusahaan, pihak kreditur, pemerintah, karyawan serta para pemegang kepentingan internal dan eksternal lainnya yang berkaitan dengan hak-hak dan kewajiban mereka atau dengan kata lain suatu sistem yang mengendalikan perusahaan. Tujuan Corporate Governance ialah untuk menciptakan nilai tambah bagi semua pihak yang berkepentingan (stakeholders).

World Bank mendefinisikan GCG adalah kumpulan hukum, peraturan dan kaidahkaidah yang wajib dipenuhi yang dapat mendorong kinerja sumber-sumber perusahaan bekerja secara efisien, menghasilkan nilai ekonomi jangka panjang yang berkesinambungan bagi para pemegang saham maupun masyarakat sekitar secara keseluruhan Konsep good 
corporate governance baru populer di Asia. Konsep ini relatif berkembang sejak tahun 1990-an. Konsep good corporate governance baru dikenal di Inggris pada Tahun 1992. Negara-negara maju yang tergabung dalam kelompok OECD (kelompok Negara-negara maju di Eropa Barat dan Amerika Utara) mempraktikkan pada Tahun 1999.

Prinsip-Prinsip GCG, menurut Keputusan Menteri BUMN Nomor 117/2002, mengenai Good Corporate Governance (GCG)

1. Transparency (Keterbukaan), yaitu keterbukaan dalam melaksanakan proses pengambilan keputusan dan keterbukaan dalam mengemukakan informasi materiil dan relevan mengenai perusahaan.

2. Accountability (Akuntabilitas), yaitu kejelasan fungsi, struktur, sistem, dan pertanggungjawaban organ perusahaan sehingga pengelolaan perusahaan terlaksana secaraefektif.

3. Responsibility (Pertanggungjawaban), yaitu kesesuaian (kepatuhan) di dalam pengelolaan perusahaan terhadap prinsip korporasi yang sehat serta peraturan perundangan yangberlaku.

4. Independency (Kemandirian), yaitu suatu keadaan dimana perusahaan dikelola secara profesional tanpa benturan kepentingan dan pengaruh/tekanan dari pihak manapun yang tidak sesuai dengan peraturan dan perundangan-undangan yang berlaku dan prinsip-prinsip korporasiyang sehat.

5. Fairness (Kesetaraan dan Kewajaran), yaitu perlakuan yang adil dan setara di dalam memenuhi hak- hak stakeholder yang timbul berdasarkan perjanjian serta peraturan perundangan yang berlaku.

Esensi dari penerapan corporate governance adalah peningkatan kinerja perusahaan melalui supervisi atau pemantauan kinerja manajemen dan adanya akuntabilitas manajemen terhadap pemangku kepentingan lainnya, berdasarkan kerangka aturan dan peraturan yang berlaku. Pada umumnya perusahaan yang mencapai keberhasilan merupakan perusahaan yang memiliki nilai etika tinggi. Hal tersebut bisa terjadi karena disaat diterapkan nilai etika bisnis tinggi, maka konsumen atau masyarakat lainnya merasa puas sehingga dilain kesempatan mereka bersedia mengikat perikatan bisnis dengan perusahaan tersebut, dengan demikian bisnis perusahaan dapat terus berkembang. Ali, (2018).

\section{TahapTahap Penerapan GCG}

Dalam pelaksanaan penerapan GCG di perusahaan adalah penting bagi perusahaan untuk melakukan pentahapan yang cermat berdasarkan analisis atas situasi dan kondisi perusahaan, dan tingkat kesiapannya, sehingga penerapan GCG dapat berjalan lancar dan mendapatkan dukungan dari seluruh unsur di dalam perusahaan. Pada umumnya perusahaan-perusahaan yang telah berhasil dalam menerapkan GCG menggunakan pentahapan berikut (Chinn, 2000; Shaw,2003).

Tahap Persiapan: Tahap ini terdiri atas 3 langkah utama: 1) awareness building, 2) GCG assessment, dan 3) GCG manual building.

1. Awareness building merupakan langkah awal untuk membangun kesadaran mengenai arti penting GCG dan komitmen bersama dalam penerapannya. Upaya ini dapat dilakukan dengan meminta bantuan tenaga ahli independen dari luar perusahaan. Bentuk kegiatan dapat dilakukan melalui seminar, lokakarya, dandiskusi kelompok.

2. GCG Assessment merupakan upaya untuk mengukur atau lebih tepatnya memetakan kondisi perusahaan dalam penetapan GCG saat ini. Langkah ini perlu guna memastikan titik awal 
level penerapan GCG dan untuk mengidentifikasi langkah-langkah yang tepat guna mempersiapkan infrastruktur dan struktur perusahaan yang kondusif bagi penerapan GCG secara efektif. Dengan kata lain, GCG assessment dibutuhkan untuk mengidentifikasi semua aspek yang perlu mendapatkan perhatian terlebih dahulu, dan langkah-langkah apa yang dapat diambil untukmewujudkannya.

3. GCG manual building, adalah langkah berikut setelah GCG assessment dilakukan. Berdasarkan hasil pemetaan tingkat kesiapan perusahaan dan upaya identifikasi prioritas penerapannya, penyusunan manual atau pedoman implementasi GCG dapat disusun. Penyusunan manual dapat dilakukan dengan bantuan tenaga ahli independen dari luar perusahaan. Manual ini dapat dibedakan antara manual untuk organ-organ perusahaan dan manual untuk keseluruhan anggota perusahaan, mencakup berbagai aspek seperti:

- Kebijakan GCG perusahaan

- Pedoman GCG bagi organ-organ perusahaan

- Pedoman perilaku

- Audit commiteecharter

- Kebijakan disclosure dantransparansi

- Kebijakan dan kerangka manajemen resiko

- Roadmap implementasi

Tahap Implementasi : Setelah perusahaan memiliki GCG manual, langkah selanjutnya adalah memulai implementasi di perusahaan. Tahap ini terdiri atas 3 langkah utama yakni:

1. Sosialisasi, diperlukan untuk memperkenalkan kepada seluruh perusahaan berbagai aspek yang terkait dengan implementasi GCG khususnya mengenai pedoman penerapan GCG. Upaya sosialisasi perlu dilakukan dengan suatu tim khusus yang dibentuk untuk itu, langsung berada di bawah pengawasan direktur utama atau salah satu direktur yang ditunjuk sebagai GCG champion di perusahaan.

2. Implementasi, yaitu kegiatan yang dilakukan sejalan dengan pedoman GCG yang ada, berdasar roadmap yang telah disusun. Implementasi harus bersifat top down approach yang melibatkan dewan komisaris dan direksi perusahaan. Imple- mentasi hendaknya mencakup pula upaya manajemen perubahan (change management) guna mengawal proses perubahan yang ditimbulkan oleh implementasiGCG.

3. Internalisasi, yaitu tahap jangka panjang dalam implementasi. Internalisasi mencakup upayaupaya untuk memperkenalkan GCG di dalam seluruh proses bisnis perusahaan kerja, dan berbagai peraturan perusahaan. Dengan upaya ini dapat dipastikan bahwa penerapan GCG bukan sekedar dipermukaan atau sekedar suatu kepatuhan yang bersifat superficial, tetapi benarbenar tercermin dalam seluruh aktivitas perusahaan.

\section{Tahap Evaluasi}

Tahap evaluasi adalah tahap yang perlu dilakukan secara teratur dari waktu ke waktu untuk mengukur sejauh mana efektivitas penerapan GCG telah dilakukan dengan meminta pihak independen melakukan audit implementasi dan scoring atas praktik GCG yang ada. Terdapat banyak perusahaan konsultan yang dapat memberikan jasa audit yang demikian, dan di Indonesia ada beberapa perusahaan yang melakukan scoring. Evaluasi dalam bentuk assessment, audit atau scoring juga dapat dilakukan secara mandatory misalnya seperti yang diterapkan di lingkungan BUMN. Evaluasi dapat membantu perusahaan memetakan kembali kondisi dan situasi serta capaian perusahaan dalam implementasi GCG sehingga dapat mengupayakan perbaikan-perbaikan yang perlu berdasarkan rekomendasi yang diberikan. 


\section{METODE PENELITIAN}

Metode penulisan yang digunakan dalam artikel ini adalah metode deskriptif, yaitu menyajikan data menganalisis dan menginterpretasikan berdasarkan implementasi terhadap kebijakan perusahaan yang dapat menggambarkan pelaksanaan Business Ethics dan penerapan Good Corporate Governance di perusahaan. Sebagian besar metode pengumpulan data dan informasi yang digunakan dalam kajian ini didapatkan dari berbagai publikasi yang ditampilkan dalam situs Bumitama Agri, Annual Report 2018, Standar Operating Prosedur Perusahaan, Code of Conduct pada PT Bumitama (BGA).

\section{HASIL DAN PEMBAHASAN}

BGA dalam menjalankan roda perusahaan telah menyusun Code of Conduct ( $\mathrm{CoC})$ yang mengatur aturan-aturan prinsip dan standard yang menuntun semua karyawan supaya memiliki kesadaran penuh untuk melakukan hal yang benar, bisnis yang dijalankan membawa kewajiban-kewajiban kepada semua pemangku kepentingan untuk tunduk terhadap Undang-undang dan ketentuan hukum yang berlaku, taat kepada kebijakankebijakan dan prinsip-prinsip Perusahaan, mengelola aset dan lingkungan dengan baik, serta bersikap bijaksana dan beretika setiap saat.

\section{Tujuan Code of Conduct}

1. Seluruh karyawan BGA Group wajib memahami bahwa segala aktivitas Perusahaan dilaksanakan berlandaskan pada prinsip-prinsip tata kelola Perusahaan yang baik.

2. Mendorong seluruh karyawan BGA Group untuk berperilaku yang baik dalam melaksanakan segala aktivitas Perusahaan.

3. Mengimplementasikan Management Risiko yang antara lain bertujuan meminimalisasi peluang terjadinya penyimpangan (fraud) yang diyakini dapat membangun dan memperkuat reputasi Perusahaan baik dalam skala nasional maupun global.

4. Merangkum informasi yang sudah diatur dan ditetapkan oleh Management terkait dengan etika dan perilaku kerja (code of conduct) yang tertuang dalam PP, IOM, SOP dan kebijakan mutu lainnya.

5. Memudahkan seluruh karyawan BGA Group mempunyai panduan etika dan perilaku yang wajib dijalankan dalam melakukan rutinitas pekerjaan sehari-hari.

6. Menghindari adanya benturan kepentingan dalam melaksanakan segala aktivitas karyawan dalam Perusahaan.

7. Mengembangkan hubungan yang harmonis, sinergi dan saling menguntungkan kepada seluruh karyawan BGA Group dan seluruh Stakeholders lainnya dengan Perusahaan yang berlandaskan prinsip-prinsip korporasi yang sehat dan beretika dalam berusaha untuk mencapai nilai-nilai dan strategi bisnis untuk menjadi Perusahaan perkebunan kelapa sawit yang berdaya saing tinggi.

\section{Manfaat Code of Conduct}

Perusahaan melaksanakan Code of Conduct ini secara konsisten dan konsekuen sehingga dapat memberikan manfaat jangka panjang bagi :

\section{Perusahaan}

1) Mendorong kegiatan operasional Perusahaan sehingga lebih efisien dan efektif dalam hubungannya dengan pemegang saham, karyawan dan masyarakat sekitar, pemerintah dan seluruh stakeholders lainnya sehingga memiliki standard etika 
yang harus diperhatikan.

2) MeningkatkanMeningkatkan nilai Perusahaan dengan memberikan kepastian dan perlindungan kepada seluruh stakeholders dalam berhubungan dengan Perusahaan sehingga menghasilkan reputasi yang baik untuk mewujudkan keberhasilan usaha dalam jangka panjang.

2. Pemegang Saham

Menambah keyakinan bagi pemegang saham bahwa Perusahaan dikelola secara profesional, berkelanjutan (sustainability), efisien, transparan, akuntabel, bertanggung jawab, mandiri dan fair untuk mencapai tingkat profitabilitas dengan tetap memperhatikan kepentingan Perusahaan.

3. Karyawan

1) Memberikan pedoman kepada setiap karyawan BGA Group tentang perilaku yang positif dan beretika serta yang dilarang oleh Perusahaan.

2) Menciptakan lingkungan kerja yang menjunjung tinggi nilai-nilai kejujuran, beretika dan keterbukaan sehingga akan meningkatkan kinerja dan produktifitas setiap karyawan BGA Group secara menyeluruh.

4. Masyarakat, Lingkungan dan Pihak Lain yang Terkait

Menciptakan hubungan yang harmonis dan saling menguntungkan antara Perusahaan dengan seluruh stakeholders lainnya yang diyakini akan menciptakan kesejahteraan ekonomi-sosial bagi masyarakat, lingkungan dan pihak lain yang terkait secara berkelanjutan.

Selain Etika bisnis, perusahaan juga menjaga konsistensi dalam tata kelola perusahaan yang baik ((Good Corporate Governance). Lima prinsip dalam GCG, yang dikenal dengan singkatan TARIF (Transparancy, Accountability; Responsibility, Independency dan Fairness) diterapkan dan dijabarkan sebagaimana yang termaktup di dalam Annual Report Tahun 2018, antara lain, prinsip prinsipnya sebagai berikut:

\section{Prinsip 1: The Board's Conduct of Affairs (Fungsi Dewan Direksi)}

- Merumuskan strategi perusahaan, keuangan tujuan dan arah untuk para Grup;

- Memastikan efektiftas manajemen kepemimpinan dari para tertinggi berkualitas dan berintegritas;

- Memberikan pengawasan internal perilaku yang tepat dari para Grup bisnis;

- Mengawasi dan / atau mengevaluasi munculnya risiko manajemen, keuangan pelaporan dan kepatuhan proses, yang dikawal oleh para Audit di internal perusahaan.

Untuk memfasilitasi manajemen yang efektif dan membantu Dewan(Board of Director) dalam melaksanakan tanggung jawabnya, fungsi-fungsi tertentu telah didelegasikan oleh Dewan kepada berbagai Komite Dewan yaitu: Komite Audit/Audit Committee(“AC"); Komite Remunerasi/ Remuneration Committee ("RC"), Komite Nominasi/Nominating Committee ("NC") ) dan Komite Resolusi Konflik/ Conflicts Resolution Committee ("CRC"), yang beroperasi dibawah kerangka acuan yang jelas, yang telah disetujui oleh Dewan dan tugasnya membantu Dewan.

\section{Prinsip 2 : Board Composition \& Guidance (Komposisi dan Panduan Dewan)}

Dewan terdiri dari enam anggota dan setengah dari Dewan adalah Direktur Independen sebagai berikut: 


\begin{tabular}{|c|c|c|c|c|c|c|}
\hline Nama & Board & $\mathbf{A C}$ & RC & NC & CRC & Year \\
\hline $\begin{array}{l}\text { Lim Gunawan } \\
\text { Hariyanto }\end{array}$ & Executive Chairman & & & & & 6.8 \\
\hline $\begin{array}{l}\text { Lim Christina } \\
\text { Hariyanto }\end{array}$ & Executive Director & & & & & 1.6 \\
\hline $\begin{array}{l}\text { Dato Lee Yeow } \\
\text { Chor }\end{array}$ & $\begin{array}{l}\text { Non Excecutive } \\
\text { Director }\end{array}$ & & & & & 6.8 \\
\hline Tan Boon Hoo & $\begin{array}{l}\text { Lead Independet } \\
\text { Director }\end{array}$ & Chairman & $\begin{array}{c}\text { Chairma } \\
\mathrm{n}\end{array}$ & $\begin{array}{c}\text { Membe } \\
\mathrm{r}\end{array}$ & $\begin{array}{c}\text { Chairmai } \\
\mathrm{n}\end{array}$ & 6.8 \\
\hline $\begin{array}{l}\text { Lee Lap Wah } \\
\text { George }\end{array}$ & $\begin{array}{l}\text { Independent } \\
\text { Director }\end{array}$ & Member & Member & $\begin{array}{c}\text { Chairm } \\
\text { an }\end{array}$ & Member & 1.6 \\
\hline $\begin{array}{l}\text { Lim Hung } \\
\text { Siang }\end{array}$ & $\begin{array}{l}\text { Independent } \\
\text { Director }\end{array}$ & Member & Member & $\begin{array}{c}\text { Membe } \\
\mathrm{r}\end{array}$ & Member & 0.6 \\
\hline
\end{tabular}

Elemen independen yang kuat dari Dewan memastikan bahwa ia dapat melakukan penilaian objektif dan independen pada urusan perusahaan dan pada transaksi yang melibatkan konflik kepentingan dan kompleksitas lainnya.

\section{Prinsip 3: Chairman and Chief Executive Officer ("CEO")}

Ketua Dewan, Bapak Lim Gunawan Hariyanto, juga adalah CEO Perusahaan. Bapak Lim Gunawan Hariyanto memainkan peran penting sebagai CEO dalam (i) merumuskan kebijakan dan strategi bisnis dan perusahaan secara keseluruhan dari Grup; (ii) mengelola keseluruhan bisnis dan operasi Grup; dan (iii) mengawasi pengembangan bisnis Grup secara keseluruhan. Sebagai Ketua Dewan, ia memikul tanggung jawab utama untuk kerja Dewan, dengan memastikan efektivitas pada semua aspek tugasnya termasuk menetapkan agenda untuk rapat Dewan dan memastikan bahwa Direksi menerima informasi yang lengkap dan memadai.

\section{Prinsip 4: Board of Membership(Keanggotaan Dewan)}

Terdiri dari tiga Direktur, ketiganya adalah Direktur Independen dan ketemu setiap semester:

1. Mr. Lee Lap Wah George (Ketua)

2. Tn. Tan Boon Hoo ( Direktur Independen Pimpinan)

3. Tn. Lim Hung Siang

Fungsi Anggota Dewan, antara lain

1. Meninjau dan merekomendasikan kepada para Dewan mengenai struktur dan komposisi dari para Dewan dan Dewan Komite.

2 Menentukan dalam proses untuk pencarian, nominasi, pemilihan dan pengangkatan dari anggota baru Dewan.

3. Meninjau dan membuat rekomendasi kepada Dewan tentang semua pengangkatan Dewan, termasuk nominasi Direksi untuk dipilih kembali / diangkat kembali, dengan mempertimbangkan kontribusi dan kinerja Direktur 
4. Menentukan setiap tahunnya apakah suatu Direktur adalah independen;

5. Menentukan mampu atau tidaknya seorang Direktur dalam melaksanakan tugasnya sebagai Direktur Perseroan, khususnya di mana para Direktur yang bersangkutan memiliki beberapa papan representasi

6. Mengevaluasi konstribusi dan kinerja para Dewan serta mengadopsi langkahlangkah yang tepat untuk menilai kinerja

7. Meninjau rencana suksesi, di khusunya yang Chairman dan CEO

\section{Prinsip 5: Board Performance (Kinerja Dewan)}

Komite Nominasi/Nominating Committee (“ The NC") telah mengadopsi penilaian tahunan mengenai efektifitas kinerja dari para Dewan dan Dewan Komite kolektif. The NC percaya itu adalah lebih tepat untuk menilai keseluruhan kinerja para Dewan, bukan menilai dari individu Dewan, sebab setiap anggota dari para Dewan memberikan kontribusi dalam berbagai cara untuk dapat efektif berkonstribusi.

Proses penilaian terus ditingkatkan, dengan umpan balik dari Dewan dan memasukkan tinjauan faktor-faktor seperti kehadiran, komposisi Dewan, perilaku, masukan dan kontribusi Dewan dan berbagai komite; menjaga tren terbaru di dalam industri pasar global; kualitas, ketersediaan dan kecukupan dari informasi. Setiap melakukan evaluasi kinerja hasilnya dikonsolidasi, dianalisis dan dibahas dalam satu forum NC, termasuk analisis performance growth melakukan perbandingan kinerja dengan tahun sebelumnya selanjutkan dilaporkan ke Dewan(Board). Ketua, dalam konsultasi dengan NC, akan bertindak atas hasil penilaian; setelah pengesahan laporan. Untuk Tahun 2018, NC umumnya puas dengan hasil evaluasi Dewan, yang mengindikasikan daerah kekuatan dan daerah yang perlu ditingkatkan lebih lanjut. Tidak ada yang signifikan masalah yang telah diidentifikasi.

\section{Prinsip 6: Access to Information (Akses informasi)}

Kemudahan akses informasi telah disediakan dalam pertemuan dengan Dewan, laporan atau makalah tinjauan tentang kinerja Grup; posisi keuangan, dan masalahmasalah utama dan signifikan, yang harus diajukan kepada Dewan dan pada periode triwulan ada laporan kinerja perasional dengan analisis /komentar singkat, hal ini untuk memastikan kemajuan/pencapaian kinerja. Direksi juga diberi informasi dari setiap perkembangan atau kejadian yang berkaitan dengan Group. Semua Direksi juga diberikan pembaharuan informasi hasil pertemuan para Dewan pertemuan, surat edaran tentang hal-hal yang berkaitan dengan, regulasi/perubahan peraturan dari SGX-ST, Companies Act, standar dan / atau persyaratan hukum lainnya. Direksi juga dapat mencari sara dari independen profesional.

\section{Prinsip 7: Prosedur untuk Mengembangkan Kebijakan Remunerasi}

Komite remunerasi /Remunaration Committee ("RC") ada tiga Direktur Independen,adalah: 
- Tn. Tan Boon Hoo (Ketua)

- Tn. Lee Lap Wah George

- Tn.Lim Hung Siang

Tugas RC meliputi:

1. Memberikan rekomendasi kepada para Dewan suatu kerangka kerja dari remunerasi untuk para Direksi dan personil manajemen kunci.

2. Memastikan bahwa paket remunerasi ini sejalan dengan pedoman Grup staf dan sepadan dengan konstribusi masing-masing karywan dan sesuai dengan lingkup penugasan pekerjaan dan tanggung jawabnya.

3. Memberikan peninjauan dan merekomendasikan biaya Direksi untuk Direktur NonEksekutif, dengan mempertimbangkan faktor-faktor seperti usaha mereka, waktu yang dihabiskan, dan responsibilitiesnya;

4. Meninjau para layanan kontrak dari para CEO dan Executive Direktur (jika ada);

5. Merekomendasikan untuk para Dewan insentif yang bersifat jangka panjang.

\section{Prinsip 8: Pengungkapan Remunerasi}

Remunerasi kebijakan dari Perusahaan untuk memberikan paket kompensasi di tingkat pasar, memberikan reward kinerja yang menarik,untuk mempertahankan dan memotivasi para manajemen kunci.

\begin{tabular}{|l|c|c|c|c|c|}
\hline \multicolumn{1}{|c|}{ Nama Direksi } & $\begin{array}{c}\text { Remunerasi } \\
\text { S \$ }\end{array}$ & $\begin{array}{c}\text { Gaji } \\
\text { Tetap }\end{array}$ & $\begin{array}{c}\text { Bonus } \\
\text { dan } \\
\text { Manfaat }\end{array}$ & $\begin{array}{c}\text { Biaya } \\
\text { Direksi }\end{array}$ & Total \\
\hline Lim Gunawan Hariyanto & $\begin{array}{c}2.500 .001- \\
2.750 .000\end{array}$ & $60 \%$ & $40 \%$ & - & $100 \%$ \\
\hline Lim Christina Hariyanto & $250.001-500.000$ & $62 \%$ & $38 \%$ & - & $100 \%$ \\
\hline Datoo Lee Yeo Chor & $<250.000$ & - & - & $100 \%$ & $100 \%$ \\
\hline Tan Boo Hoo & $<250.000$ & - & - & $100 \%$ & $100 \%$ \\
\hline Lee Lap Wah George & $<250.000$ & - & - & $100 \%$ & $100 \%$ \\
\hline Lim Hung Siang & $<250.000$ & - & - & $100 \%$ & $100 \%$ \\
\hline $\begin{array}{l}\text { Chua Chun Guan } \\
\text { Christopher }\end{array}$ & $<250.000$ & - & - & $100 \%$ & $100 \%$ \\
\hline
\end{tabular}

Eksekutif Kunci :

\begin{tabular}{|l|c|c|c|c|c|}
\hline \multicolumn{1}{|c|}{ Nama Direksi } & Remunerasi S \$ & $\begin{array}{c}\text { Gaji } \\
\text { Tetap }\end{array}$ & $\begin{array}{c}\text { Bonus } \\
\text { dan } \\
\text { Manfaat }\end{array}$ & $\begin{array}{c}\text { Biaya } \\
\text { Direksi }\end{array}$ & Total \\
\hline 2 eksekutif & $\begin{array}{c}1.750 .000- \\
2.000 .000\end{array}$ & 0.59 & 0.41 & & $100 \%$ \\
\hline 1 eksekutif & $\begin{array}{c}1.250 .001- \\
1.500 .000\end{array}$ & 0.46 & 0.54 & & $100 \%$ \\
\hline
\end{tabular}

Ada tiga karyawan, yang merupakan anggota keluarga langsung seorang Direktur dan / atau CEO yang remunasinya melebihi S \$ 50.000 selama Tahun 2018. Informasi ini tercantum di bawah ini:

Nama

Hubungan Remunerasi S\$ 


\begin{tabular}{|l|l|c|}
\hline \multicolumn{1}{|c|}{ Eksekutif } & & $50,001-100,000$ \\
\hline Michael Raben & $\begin{array}{l}\text { Kakak Ipar dari Lim Gunawan } \\
\text { Hariyanto dan Lim Christina } \\
\text { Hariyanto }\end{array}$ & $\begin{array}{l}\text { Saudara Perempuan Lim Gunawan } \\
\text { Hariyanto dan Lim Christina } \\
\text { Hariyanto }\end{array}$ \\
\hline Lim Liana Sarwono & $\begin{array}{l}\text { Kakak dari im Gunawan Hariyanto } \\
\text { dan Lim Christina Hariyanto }\end{array}$ & $\begin{array}{c}1,150,001- \\
1,200,000\end{array}$ \\
\hline $\begin{array}{l}\text { Gunardi Hariyanto } \\
\text { Lim* }\end{array}$
\end{tabular}

* Sebagai Kepala Komisaris dari PT Bumitama Gunajaya Agro sejak 2018

\section{Prinsip 9: Akuntabilitas}

Dewan mempromosikan pengungkapan yang tepat waktu dan seimbang atas semua materi yang terkait dengan Grup. Pemegang saham dimutakhirkan mengenai operasi dan posisi keuangan Grup melalui pengumuman hasil kuartalan dan setahun penuh (sejalan dengan Standar Pelaporan Keuangan pori-pori Singa (International) yang ditentukan oleh Dewan Standar Akuntansi Singapura) serta pengumuman tepat waktu mengenai hal-hal lain seperti yang ditentukan oleh Manual Pendaftaran SGX- ST dan peraturan dan ketentuan terkait lainnya. Ringkasan dari sorotan operasional Grup yang disiapkan setiap triwulan juga dirilis melalui SGXNet.

\section{Prinsip 10: Manajemen Risiko dan Pengendalian Internal}

Dewan mengakui bertanggung jawab untuk memastikan bahwa Manajemen memelihara sistem kontrol internal yang sehat untuk menlindungi investasi Pemegang Saham dan aset Grup.

Dewan secara teratur meninjau dan meningkatkan kegiatan bisnis dan operasionalnya untuk mengidentifikasi bidang- bidang risiko bisnis yang signifikan serta mengambil langkah langkah yang tepat untuk mengendalikan dan mengurangi risiko-risiko ini. Manajemen ulasan semua kontrol kebijakan dan prosedur dan menyoroti semua hal signifikan dengan Audit Committee (AC) dan Dewan. Faktor risiko keuangan dan tujuan manajemen risiko keuangan dan kebijakan yang diuraikan di bawah Catatan 36 dari "Catatan atas Laporan Keuangan” pada halaman 122 untuk 132. Risiko manajemen saja tidak menjamin bahwa usaha bisnis tidak akan fail. Namun, dengan mengidentifikasi dan mengelola risiko yang mungkin timbul, AC dan para Dewan dapat menjaga keuntungan dengan membuat keputusan yang seimbang untuk imbalan dan resiko serta melindungi aset Grup. AC, bersama Dewan telah menelaah keefektifan sistem kontrol internal Grup untuk menangani risiko keuangan, operasional, kepatuhan, dan teknologi informasi utama yang mempengaruhi operasi.

\section{Prinsip 11: Manajemen Risiko Enterp Rise("ERM")}

Manajemen risiko yang efektif dan bijaksana adalah salah satu faktor utama dalam mencapai tujuan bisnis dan sasaran strategis Grup. 
Grup telah membentuk kerangka kerja ERM yang sistematis untuk mengidentifikasi, menilai, memantau, mengelola, dan menilai risiko bisnis signifikan yang dihadapi Grup. Di bawah kerangka ERM, daftar risiko yang mengidentifikasi risiko material bersama dengan kontrol internal untuk mengelola atau memitigasi risiko tersebut dipertahankan. Komite Manajemen yang terpisah dan Departemen Risiko Perusahaan dibentuk untuk mengawasi ERM dan memastikan bahwa daftar risiko ditinjau, dikelola, dan diperbarui secara berkala.

Komite Manajemen terdiri dari Chief Operating Officer, CFO, Wakil Chief Operating Officer, Group Head Layanan Sekretaris Perusahaan dan Tanggung Jawab Sosial Perusahaan (GH CSS \& CSR) serta Kepala Departemen Audit Internal.

\section{Prinsip 12: Audit Internal (IA)}

Tim audit internal ("IA") yang berdedikasi siap untuk meninjau, setidaknya sekali setiap tahun, risiko kebijakan, prosedur, dan kegiatan Grup. IA memiliki gratis akses ke semua dari para Grup catatan dan dokumen dan laporan langsung ke dalam AC pada setiap materi non-kepatuhan dan internal yang kontrol kelemahan.

Kepala IA melapor langsung kepada Ketua AC mengenai masalah-masalah audit dan kepada CFO tentang masalah-masalah administrasi. Kepala IA juga berbagi laporan IA dengan Manajemen untuk memastikan bahwa tindakan korektif dan pencegahan yang direkomendasikan telah diambil langkah perbaikan. Setiap kuartal, IA menyiapkan laporan audit internal dan melaporkan masalah-masalah utama, menyoroti kekhawatiran, jika ada, ke AC. Umpan balik dari AC diperhatikan, ditindaklanjuti, dan dimonitor . Dalam kerangka ini, fungsi audit internal memberikan keyakinan yang masuk akal bahwa risiko Grup akan diidentifikasi, dianalisis, dan dikelola oleh Manajemen. IA juga akan membuat rekomendasi untuk meningkatkan efektivitas dan keamanan operasi Grup.

\section{Prinsip ke 13: Kebijakan Dividen}

Grup memiliki kebijakan dividen untuk mendistribusikan hingga $40 \%$ dari pendapatan yang dapat dibagikan. Kebijakan pembagian dividen tergantung pada hasil Grup arus kas dan posisi keuangan, rencana belanja modal, jadwal pembayaran utang, dividen yang diterima dari perusahaan anak perusahaan, industri kondisi dan prospek, dan lainnya faktor yang dianggap relevan oleh para Dewan Direksi. Untuk Tahun 2018, Grup telah mengumumkan dan membayar dividen interim sebesar S \$ 0,0075 per saham biasa pada 14 September 2018. Dividen final sebesar S \$ 0,02 per saham biasa untuk Thn 2018 telah direkomendasikan oleh Dewan dan tunduk pada persetujuan oleh Pemegang Saham pada RUPS yang akan datang.

\section{KESIMPULAN DAN SARAN}

Dalam menjalankan roda perusahaan, PT Bumitama Agri, sebagai perusahaan publik telah konsisten menjalankan bisnis yang dilandasi oleh sebuah nilai nilai moral, dan menjunjung tinggi Etika bisnis, dengan 3 pilar penyangga utama yaitu: Moralitas, Kapablitas 
dan Integritas. Hal ini untuk mewujudkan Visi dan Misi Perusahaan. Dalam implementasinya didukung dengan penerapan Code of Conduct untuk menuntun semua karyawan dalam menjalankan segenap aktivitas di perusahaan berdasarkan prinsip prinsip etika bisnis secara konsisten dan konsekuen sehingga dapat memberikan manfaat jangka panjang bagi Perusahaan, shareholder/Pemegang Saham, dan stakeholders lainnya (Karyawan; masyarakat sekitar, mitra perusahaan).

Sejalan dengan penerapan etika bisnis, perusahaan juga sudah menerapkan Tata Kelola Perusahaan secara baik (Good Corporate Governance), dengan menjalankan prinsip prinsip GCG, yakni Transparancy, Accountability, Responsibility, Independence dan Fairness. Implementasi prinsip prinsip GCG diuatarakan dalam artikel ini, minimal ada 13 prinsip. Dengan demikian semua hak hak shareholders dan stakeholders telah dipenuhi secara tepat dan akurat, misalnya hak untuk mendapatkan informasi perkembangan operasi perusahaan, informasi dalam proses pengambilan keputusan, informasi tentang Dewan Direksi dan kewenangan perangkat organ perusahaan. Dengan diterapkannya Business Ethic dan Good Corporate Governance ada peningkatan kinerja perusahaan, dan ini telah dibuktikan oleh Perusahaan Bumitama, dengan diperolehnya berbagai penghargaan dari tahun ke tahun. Tantangan kedepan adalah konsistensi untuk mempertahankannya terutama adalah Pertumbuhan Kinerja Perusahaan.

\section{DAFTAR RUJUKAN}

Ali, Hapzi .2018. Modul BE \& GG. Univeristas Mercu Buana. Jakarta

Annual Report. 2018. Bumitama Agri

Bank, World, Corporate Governance Country Assess- ment : Republic of Indonesia, Jakarta, 2005.

Bertens, K. 1993. “Etika Bisnis Menjadi Urusan Siapa?”. Seminar “ Etika Bisnis dalam Rangka Pembentukan Hukum

Bisnis di Indonesia". Bandung: Senat Mahasiswa Fakultas Hukum Universitas Parahyangan, 7-8 Mei.

Bertens, K. 2000. Pengantar Etika Bisnis. Yogyakarta: Penerbit Kanisius

Chinn, Richard, Corporate Governance Handbook, Gee Publishing Ltd. London, 2000.

Daniri Mas Ahmad, Good Corporate Governance : Konsep dan Penerapannya di Indonesia. Ray Indonesia, Jakarta, 2005.

https://databoks.katadata.co.id/datapublish/2018/07/08/jumlah-penduduk-indonesia-akanmencapai-puncaknya-pada-2062

Keputusan Menteri BUMN Nomor 117/2002, mengenai Good Corporate Governance (GCG)

Moeljono, Djokosantoso, Good Corporate Culture sebagai inti dari Good Corporate Governance, Elex-Gramedia, Jakarta, 2005.

Monks, Robert A.G, dan Minow, N, Corporate Governance $3^{\text {rd }}$ Edition, Blackwell Publishing, 2003.

Muslich. 1998. Etika Bisnis Pendekatan Substantif dan Fungsional. Yogyakarta: Penerbit 
Ekonisia

Robin, Donald P. dan R. Eric Reidenbach. 1987. Social Responsibility, Ethics, and Marketing Strategy: Closing the Gap Between Concept and Application, Journal of Marketing. Vol. 51 January 44-58.

Shaw, John. C, Corporate Governance and Risk: A System Approach, John Wiley \& Sons, Inc, New Jersey, 2003.

Silalahi, Gabriel Amin. 2003. Strategi Etika Bisnis dan Studi Kasus. Sidoarjo: Citramed 